\title{
UPAYA GURU DALAM MENGAJARKAN KETERAMPILAN MEMBACA SISWA PADA MASA PANDEMI COVID-19 DI SDN GUGUS IV KECAMATAN PUJUT
}

\author{
Devi Ayuniar ${ }^{1}$, Lalu Hamdian Afandi ${ }^{2}$, Heri Setiawan ${ }^{3}$ \\ ${ }^{1,2,3}$ Program Studi Pendidikan Guru Sekolah Dasar, Universitas Mataram, Mataram, Indonesia
}

\begin{abstract}
Informasi Artikel
Riwayat Artikel:

Diserahkan: 16-10-2020

Direvisi: 21-10-2020

Dipublikasikan: 11-01-2021

\section{Kata-kata kunci:}

Upaya guru

Pandemi

COVID-19

Keterampilan membaca

ABSTRAK

Tujuan dari penelitian ini adalah untuk mengetahui upaya guru dalam mengajarkan keterampilan membaca siswa SD pada masa pandemi Covid-19 SDN Gugus IV Kecamatan Pujut. Metode penelitian yang digunakan adalah metode kualitatif jenis fenomenologi dengan pendekatan deskriptif. Sumber data dalam penelitian ini adalah guru wali kelas 1-6 SDN Gugus IV Kecamatan Pujut. Penentuan sumber data dalam penelitian ini menggunakan teknik purposive sampling. Metode pengumpulan data yaitu menggunakan angket terbuka yang diberikan kepada masing-masing guru wali kelas 1-6. Data yang diperoleh kemudian di analisis menggunakan teknik analisis data Interaktif Analysis Model dari Miles dan Huberman. Berdasarkan hasil angket dapat disimpulkn bahwa upaya guru dalam mengajarkan keterampilan membaca siswa SD pada masa pandemi Covid-19 SDN Gugus IV Kecamatan Pujut adalah guru menentukan metode yang cocok, memberikan motivasi, pujian, hadiah, dan nilai kepada siswa, literasi di awal pembelajaran, dan memberikan tugas yang mengharuskan kegiatan membaca.
\end{abstract}

This is an open access article under the CC BY-SA license.

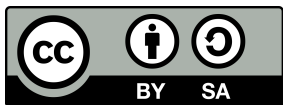

\section{Penulis Korespondensi:}

Devi Ayuniar,

Program Studi Pendidikan Guru Sekolah Dasar, Universitas Mataram,

J1. Brawijaya No.22, Cakranegara, Kota Mataram, Indonesia.

Email: deviayuniar171108@gmail.com

\section{PENDAHULUAN}

Pembelajaran Bahasa Indonesia merupakan pembelajaran yang kompleks dengan mengutamakan aspek keterampilan berbahasa. Keterampilan berbahasa mencakup empat komponen, yaitu keterampilan menyimak, keterampilan membaca, keterampilan berbicara dan keterampilan menulis. Dengan membaca siswa dapat memahami bahasa tulis dan pembendaharaan kata. Tarigan (1985) berpendapat bahwa membaca merupakan suatu proses yang dilakukan serta dipergunakan oleh pembaca untuk memperoleh pesan, yang hendak disampaikan oleh penulis melalui media kata-kata/bahasa tulis. Membaca merupakan kegiatan yang penting untuk dilakukan. Karena dengan membaca siswa dapat memahami bahasa tulis dan menambah pembendaharaan kata. Dalam membaca diperlukan keseriusan untuk mendapatkan hasil yang maksimal. Membaca sebagai suatu keterampilan berbahasa memiliki tujuan, yaitu: (1) ingin mengetahui tentang beberapa topik atau masalah; (2) memperkaya perbendaharaan bahasa; (3) memerlukan instruksi untuk dapat melaksanakan beberapa tugas dalam pekerjaan atau kehidupan sehari-hari; dan (4) memperbaiki pemahaman (Musaddat, 2017). 
Pada masa pandemi sekarang ini proses pembelajaran dilakukan dengan cara pembentukan kelompokkelompok kecil dan dilakukan di rumah siswa atau dikenal dengan sebutan BDR (Belajar Dari Rumah). Hal tersebut sesuai dengan Surat Edaran Menteri No 4 Tahun 2020 pada tangal 24 Maret 2020 tentang proses belajar dari rumah dilaksanakan dengan ketentuan sebagai berikut: (1) belajar dari rumah melalui pembelajaran daring/jarak jauh dilaksanakan untuk memberikan pengalaman belajar yang bermakna bagi siswa, tanpa terbebani tuntutan menuntaskan seluruh capaian kurikulum untuk kenaikan kelas maupun kelulusan; (2) Belajar dari rumah dapat difokuskan pada pendidikan kecakapan hidup antara lain mengenai pandemi Covid-19; (3) Aktivitas dan tugas pemebalajaran belajar dari rumah dapat bervariasi antarsiswa, sesuai minat dan kondisi masing-masing, termasuk mempertimbangkan kesenjangan akses/fasilitas belajar di rumah; dan (4) Bukti atau produk aktivitas belajar dari rumah diberi umpan balik yang bersifat kualitatif dan berguna dari guru, tanpa diharuskan memberi skor/nilai kuantitatif.

Terkait dengan Surat Edaran Menteri Pendidikan dan Kebudayaan No 4 Tahun 2020 di atas pada tanggal 24 Maret 2020 keluarlah penegasan Surat Edaran Gubernur NTB pada tanggal 22 Juli 2020 yang menyatakan bahwa penyelenggaraan pembelajaran di satuan pendidikan pada tahun pelajaran 2020/2021 di masa pandemi Corona Virus Disease-19 (Covid-19), dengan ini disampaikan penegasan bahwa penyelenggaraan pemebalajaran di satuan pendidikan di Kabupaten /Kota se-NTB: (1) Pada semua zona (Hijau, Merah, Orange, dan Kuning) tidak diperkenankan menyelenggarakan Masa Pengenalan Lingkungan Sekolah (MPLS) tatap muka; (2) Pemebelajaran awal tahun pembelajaran 2020/2021 tidak diperkenanakan melaksanakan tatap muka namun dilakukan dalam jaringan.

Berdasarkan hasil observasi dan wawancara yang dilakukan pada tanggal 17 juni 2020 di SDN gugus IV Kecamatan Pujut, ditemukan permasalahan bahwa proses pembelajaran belum berlangsung dengan efektif. Ketidakefektifan proses pembelajaran tersebut disebabkan karena beberapa hal diantaranya rata-rata siswa hanya mampu kosentrasi 2/3 menit. Hal ini dipengaruhi oleh ruang yang bebas, tidak ada yang mengawasi setiap waktu, cenderung melakukan hal-hal yang lebih menyenangkan seperti bermain dengan teman atau bahkan disibukkan dengan bermain gim. Hal ini terlihat dari hasil pengamatan yang dilakukan peneliti terhadap siswa pada saat melakukan aktivitas pembelajaran di rumahnya yang menunjukkan bahwa siswa cenderung cepat bosan. Sehingga peneliti ingin mengetahui apa saja upaya guru dalam mengajarkan keterampilan membaca siswa SD pada masa pandemic Covid-19 SDN Gugus IV Kecamatan Pujut.

\section{METODE PENELITIAN}

Metode penelitian yang digunakan dalam penelitian ini adalah metode kualitatif jenis fenomenologi dengan pendekatan deksriptif. Penelitian ini dilaksanakan pada semester ganjil di SDN Gugus IV Kecamatan Pujut pada Tahun Ajaran 2020/2021. Sumber data pada penelitian ini adalah guru wali kelas 1-6 di SDN Gugus IV Kecamatan Pujut, yang berjumlah 48 orang guru. Teknik penentuan sumber data adalah dengan menggunakan purposive sampling. Karena yang ingin di lihat disini adalah bagaimana cara mengajar guru wali kelas 1-6 di SDN Gugus IV Keccamatan Pujut.

Instrumen penelitian adalah alat ukur yang digunakan dalam suatu penelitian. Menurut Arikunto (2013), instrumen diartikan sebagai alat bantu bagi peneliti dalam menggunakan metode pengumpulan data. Adapun instrumen dalam penelitian ini adalah dengan menggunakan angket. Kuesioner adalah teknik pengumpulan data melalui pertanyaan-pertanyaan tertulis untuk mendapatkan informasi dari sumber data (Syahrum \& Salim, 2014). Angket terbuka merupakan angket yang memberikan kebebasan kepada responden untuk menjawab. Peneliti menggunakan angket karena untuk mengetahui upaya guru dalam mengajarkan keterampilan membaca pada kondisi pandemi sekarang ini sangat cocok dilakukan dengan mengajukan berbagai pertanyaanpertanyaan kepada guru guna untuk mendapatkan informasi yang jelas. Dan untuk teknik analisis data menggunakan teknik analisis data Interaktif Analysis Model dari Miles dan Huberman (Sugiyono, 2016). Penelitian ini akan dilaksanakan dengan cara menyebarkan angket ke masing-masing responden di setiap SD yang ada di Gugus IV Kecamatan Pujut. Sebelum angket di berikan terlebih dahulu responden diberitahukan terkait dengan kisi-kisi dari angket yang akan diisi. Setelah itu barulah angket diberikan kepada responden. Kemudian responden langsung mengisi angket tersebut sampai selesai. Penelitian survei ini dilakukan 6 hari.

\section{HASIL DAN PEMBAHASAN}

Adapun hasil dari penelitian ini adalah (1) Memanfaatkan waktu yang relatif terbatas; (2) Guru meberikan motivasi, pujian, dan nilai kepada siswa; (3) Guru menentukan metode pembelajaran yang sesuai 
dengan karakteristik materi dan karakteristik siswa; (4) memberikan bimbingan khusus pada siswa yang berkemampuan membaca rendah; (5) Memberikan evaluasi di setiap pertemuan; (6) Membudayakan literasi di setiap awal pembelajaran; (7) Menyediakan sarana dan prasarana yang menunjang keterampilan membaca siswa; (8) Guru bekerja sama dengan orang tua siswa.

Waktu pokok dalam belajar berbeda antara kelas rendah dan kelas tinggi. Seperti biasa dalam kondisi normal pun waktu belajar untuk siswa kelas rendah lebih sedikit daripada kelas tinggi. Pada masa pandemi sekarang ini terkait dengan waktu pembelajaran yang terbatas, guru pun harus berfikir keras supaya bisa menyajikan proses pembelajaran yang bermakna dan menyenangkan. Karena berdasarkan Surat Edaran Menteri No 4 Tahun 2020 dan Surat Penegasan Gubernur NTB yang dikeluarkan pada tanggal 22 Juli 2020 yaitu proses pembelajaran dilakukan dari rumah atau dikenal dengan sistem BDR.

Pada sistem BDR ini guru di tuntut untuk memberikan pengalaman belajar yang bermakna untuk siswa, tanpa terbebani tuntutan menuntaskan seluruh capaian kurikulum untuk kenaikan kelas maupun kelulusan. Berdasarkan hasil angket, metode yang paling sering digunakan oleh guru SDN Gugus IV Kecamatan Pujut adalah metode penugasan, kartu kata, ceramah, tanya-jawab, dan diskusi. Dalam suatu proses belajar mengajar, dua unsur yang amat penting adalah metode mengajar dan media pembelajaran (Turrahmi, Erfan, \& Yahya, 2017). Metode yang digunakan oleh guru dimaksudkan supaya siswa melakukan kegiatan membaca. Sebelum metode tersebut diterapkan guru memperhatikan karakteristik siswa dan materi terlebih dahulu. Seperti pada kelas rendah guru lebih menerapkan metode yang melibatkan siswa secara langsung seperti belajar sambil bermain. Dikarenakan karakteristik siswa kelas rendah yang senang merasakan atau memperagakan sesuatu secara langsung ditinjau dari teori perkembangan kognitif siswa SD memasuki tahap operasional kongkrit. Untuk siswa kelas tinggi guru menerapkan metode ceramah, pemberian tugas, dan diskusi. Karena karakteristik untuk kelas tinggi siswa rasa ingin tahunya tinggi, siswa memandang nilai sebagai ukuran yang tepat mengenai prestasi belajarnya, dan siswa gemar membentuk kelompok sebaya untuk bermain bersama.

Semua guru SDN Gugus IV Kecamatan Pujut membiasakan siswanya untuk melakukan kegiatan literasi di awal pembelajaran. Salah satu contoh guru kelas IV di SDN Bedus disetiap awal pembelajaran wajib melakukan kegiatan membaca selama 15 menit terlebih dahulu. Pada kegiatan literasi ini siswa dibiarkan membaca apa saja baik itu cerita fiksi maupun nonfiksi. Bahan bacaan didapat dari buku siswa yang diberikan oleh sekolah dan kadang-kadang disedikan oleh guru. Metode yang sering digunakan oleh guru tersebut adalah metode membaca menyenangkan, membaca sekilas, dan membaca variatif. Hal tersebut sesuai dengan pendapat Tampubolon dalam Dalman (Dalman, 2017), ada banyak teknik membaca yang dapat diterapkan oleh guru dalam proses pembelajaran seperti (1) baca-pilih; (2) baca-lompat; (3) baca-layap; (4) baca-tatap. Untuk di kelas rendah guru lebih memilih metode membaca berulang, kerena siswa belum terlalu lancar dalam membaca. Untuk menumbuhkan semangat siswa dalam membaca semua guru sepakat dengan menjawab memberikan motivasi, pujian, nilai dan hadiah kepada siswa. Karena dengan seperti itu siswa termotivasi ada rasa ingin melakukannya karena ada timbal balik dari guru. Karena untuk keterampilan membaca bukanlah suatu hal yang mudah untuk dilakukan bagi setiap siswa. Jadi guru mensiasatinya dengan memberikan motivasi atau bahkan hadiah kepada siswa yang melakukan kegiatan membaca. Karena menurut Lamb dan Arnold dalam Musaddat (2017), keterampilan membaca itu sendiri dipengaruhi oleh beberapa faktor seperti faktor fisiologis, faktor intelektual, faktor lingkungan, dan faktor psikologis. Keempat faktor ini saling berhubungan antara yang satu dengan yang lainnya. Atau dapat dikatakan sebagai satu kesatuan yang saling mempengaruhi. Sehingga selanjutnya tugas guru bagaimana supaya dapat menjadi pendidik atau pembimbing yang bisa menguasai setiap faktor tersebut, kecuali faktor fisiologi.

Pemberian motivasi ini dilakukan guru dengan meberikan kata-kata mutiara atau wejangan kepada siswa. Misalnya seperti "rugi kalau dalam satu hari itu kita tidak melakukan kegiatan membaca karena siswa tau dengan membaca kita bisa menjadi orang yang no 1 di dunia jika siswa tidak membaca maka bisa jadi tidak naik kelas dan tidak akan bisa menjadi no 1 di dunia”. Dan kadang-kadang guru juga menjanjikan nilai yang bagus bagi siswa yang melakukan kegiatan membaca.

Tahapan dalam membaca itu tidak semudah seperti yang dibayangkan. Tahapan membaca itu memiliki sintaks yaitu: (1) sensori; (2) perseptual; (3) pengalaman; (4) berpikir; dan (5) sikap (Santoso, Rosdiana, Ms, Setiawati, \& Prakoso, 2014). Jadi tahapan-tahapan inilah yang sedang dicoba oleh guru demi membentuk keterampilan membaca siswa yang baik. Yang dimulai dari memberikan motivasi, hadiah, literasi, membaca sekilas, membaca variaif, dan lain-lain.

Untuk menunjang keterampilan membaca siswa SD dari sekolah menyediakan sarana dan prasarana berupa buku siswa, LKS, dan buku-buku cerita lainnya yang bisa dibawa oleh masing-masing siswa ke rumah- 
nya. Karena siswa yang memiliki bahan bacaan di rumah pasti keterampilan membacanya lebih bagus daripada siswa yang tidak memiliki bahan bacaan di rumahnya. Faktor lingkungan merupakan salah satu faktor yang pengaruhnya besar terhadap keterampilan membaca siswa.

Bagi siswa yang memiliki keterampilan membaca rendah sebagian besar guru mengatasinya dengan memberikan bimbingan khusus kepada siswa tersebut. Bimbingan khusus ini berupa pemberian tugas yang lebih dari siswa yang lainnya dan pembimbingan di luar jam pelajaran. Jadi untuk siswa yang memiliki keterampilan membaca rendah mendapatkan bimbingan yang lebih dari guru. Bimbingan ini dapat berupa melakukan kegiatan membaca di depan guru, dan diskusi dengan guru terkait dengan apa saja kesulitan yang di alami oleh siswa yang menyebabkan keterampilan membacanya rendah.

Pada setiap pertemuan untuk mengetahui sejauh mana aktivitas siswa dalam membaca atau belajar guru memberikan evaluasi sesuai dengan materi yang dibahas pada hari itu. Untuk kelas rendah guru memberikan bahan bacaan yang dilengkapi dengan pertanyaan-pertanyaan seputar dengan bahan bacaan tersebut. Kemudian siswa menjawabnya. Selanjutnya untuk kelas tinggi siswa melakukan kegiatan membaca secara mandiri karena di setiap akhir pembelajaran akan ada tugas yang diberikan oleh guru. Mengumpulkan data membaca pemahaman bisa menggnakan tes, kuesioner, dan wawancara. Dan disini guru menggunakan tes untuk mengukur sejauh mana aktivitas siswa dalam membaca (Soleimani \& Hajghani, 2013).

Demi efektifnya proses pembelajaran dari rumah guru bekerja sama dengan orang tua dalam melakukan pembimbingan dan pengawasan terhadap aktivitas siswa di rumah. Karena guru juga membutuhkan dukungan yang berkelanjutan mengenai pengajaran pemahaman bacaan (Ness, 2011). Keterlibatan orang tua dapat berupa memberikan bimbingan belajar, selalu memberikan nasehat, memberikan motivasi, memenuhi kebutuhan anaknya, dan memberikan pengawasan. Keterlibatan orang tua ini termasuk kedalam faktor lingkungan yang mempengaruhi keterampilan membaca siswa.

Upaya guru dalam mengajarkan keterampilan membaca pada masa pandemi sekarang ini sedikit berbeda dengan proses pembelajaran sebelum pandemi melanda. Yang membedakannya adalah metode yang digunakan oleh guru lebih dominan memberikan tugas kepada siswa. Karena waktu belajar dengan bimbingan guru secara langsung sangat sedikit. Jadi untuk mengontrol siswa melakukan kegiatan belajar mandiri di rumah, guru mensiasatinya dengan memberikan tugas yang berkelanjutan.

Hasil penelitian ini dapat disimpulkan bahwa upaya guru dalam mengajarkan keterampilan membaca siswa SD pada masa pandemi adalah guru menentukan metode yang cocok, memberikan motivasi, pujian, hadiah, dan nilai kepada siswa, guru menentukan metode pembelajaran yang sesuai dengan karakteristik materi dan karakteristik siswa, memberikan bimbingan khusus kepada siswa yang memiliki keterampilan membaca rendah, memberikan evaluasi di setiap pertemuan, membudayakan literasi di awal pembelajaran, dan menyediakan sarana dan prasarana yang menunjang keterampilan membaca siswa.

Hal tersebut sesuai dengan hasil penelitian yang dilakukan oleh Fauziah (2018), upaya guru dalam mengembangkan kemampuan membaca, menulis permulaan diantaranya yaitu dengan memberikan les tambahan, memberikan buku bacaan, memanfaatkan waktu belajar dengan baik, mendikte siswa, menggunakan metode membaca eja dan membaca lancar, memberikan motivasi, memberikan reward, memberikan bimbingan dan pengawasan, mengajak ke perpustakaan, dan memberikan penilaian. Selanjutnya penelitian yang dilakukan oleh Rahman dan Haryanto (2014) yang menyatakan bahwa dengan penggunaan media flashcard dapat meningkatkan keterampilan membaca siswa kelas rendah.

\section{SIMPULAN}

Berdasarkan hasil penelitian yang telah dilakukan, maka dapat disimpulkan bahwa upaya guru dalam mengajarkan keterampilan membaca pada masa pandemi Covid-19 SDN Gugus IV Kecamatan Pujut ialah (1) Memanfaatkan waktu yang relative terbatas; (2) Guru memberikan motivasi, pujian, dan nilai kepada siswa; (3) Guru menentukan metode pembelajaran yang sesuai dengan karakteristik materi dan karakteristik siswa; (4) Memberikan bimbingan khusus kepada siswa yang memiliki keterampilan membaca rendah; (5) Memberikan evaluasi di setiap pembelajaran; (6) Membudayakan literasi disetiap awal pembelajaran; (7) Menyediakan sarana dan prasarana yang menunjang keterampilan membaca siswa; (8) Guru bekerjasama dengan orang tua siswa. Sebaiknya guru lebih kreatif lagi dalam merancang pembelajaran demi tercapinya tujuan pembelajaran. Dan juga dari sekolah hendaknya lebih meningkatkan lagi sarana dan prasarana yang menunjang keterampilan siswa dalam membaca. 


\section{DAFTAR PUSTAKA}

Arikunto, S. (2013). Manajemen Penelitian. Jakarta: PT. Rineka Cipta.

Dalman. (2017). Keterampilan Membaca. Jakarta: PT Raja Grafindo Persada.

Fauziah, H. (2018). Upaya Guru dalam Mengembangkan Kemampuan Membaca Menulis Permulaan Siswa Kelas I MI. Elementary: Jurnal Ilmiah Pendidikan Dasar, 4(2), 173. doi:10.32332/elementary.v4i2.1241

Musaddat, S. (2017). Peningkatan Keterampilan Berbahasa Indonesia SD. Mataram: Arga Puji Press.

Ness, M. (2011). Explicit Reading Comprehension Instruction in Elementary Classrooms: Teacher Use of Reading Comprehension Strategies. Journal of Research in Childhood Education, 25(1), 98-117. doi:10. 1080/02568543.2010.531076

Rahman, B., \& Haryanto, H. (2014). Peningkatan Keterampilan Membaca Permulaan Melalui Media Flashcard pada Siswa Kelas I SDN Bajayau Tengah 2. Jurnal Prima Edukasia, 2(2), 127. doi:10.21831/jpe.v2i2. 2650

Santoso, A., Rosdiana, Y., Ms, Z., Setiawati, L., \& Prakoso, T. (2014). Materi dan Pembelajaran Bahasa Indonesia SD. Tangerang Selatan: Universitas Terbuka.

Soleimani, H., \& Hajghani, S. (2013). The Effect of Teaching Reading Comprehension Strategies on Iranian EFL Pre-University Students' Reading Comprehension Ability.

Sugiyono. (2016). Metode Penelitian dan Pengembangan (Research and Development/R\&D). Bandung: Alfabeta.

Syahrum, S., \& Salim, S. (2014). Metodologi Penelitian Kuantitatif. Bandung: Citapustaka Media.

Tarigan, H. G. (1985). Berbicara: sebagai suatu keterampilan berbahasa. Bandung: Angkasa.

Turrahmi, N., Erfan, M., \& Yahya, F. (2017). Pengembangan Media Pembelajaran Video Berbasis Microsoft Office Power Point Pada Materi Objek IPA dan Pengamatannya. Quark: Jurnal Inovasi Pembelajaran Fisika dan Teknologi. doi:10.31227/osf.io/t6ky9 